\title{
Comparison of Radiological Imaging and Reverse Transcriptase Polymerase Chain Reaction Test in Preoperative Screening for Detection of COVID-19
}

\author{
Preoperatif Değerlendirmede COVID-19 Tanısında Radyolojik \\ Görüntülemenin ve Ters Transkriptaz Polimeraz Zincir Reaksiyonu \\ Testinin Karşılaştırılması
}

\section{(D) Güler Özgül1, (D Efsun Gonca Uğur Chousein²}

1University of Health Sciences Turkey, İstanbul Bağcllar Training and Research Hospital, Clinic of Chest Diseases and Tuberculosis, İstanbul, Turkey

${ }^{2}$ University of Health Sciences Turkey, Yedikule Chest Diseases and Thoracic Surgery Education and Research Hospital, Clinic of Chest Diseases and Tuberculosis, İstanbul, Turkey

\section{Abstract}

Objective: It was aimed to compare the diagnostic rates of radiological diagnostic methods such as chest $\mathrm{X}$-rays and chest computerized tomography (CCT) and swab (throat and nose) reverse-transcriptase polymerase chain reaction test (RT-PCR) in preoperative screening for the detection of Coronavirus disease-2019 (COVID-19) infection.

Method: One hundred-seven preoperative patients who were asymptomatic for COVID-19 were retrospectively evaluated. Their demographic data were evaluated along with RT-PCR test results, chest $\mathrm{X}$-rays and CCTs defined according to the Radiological Society of North America expert consensus on COVID-19.

Results: Chest X-rays were performed in 55 (51.4\%) cases, and CCT in 52 (48.6\%) patients. None of the chestX-rays displayed findings of COVID-19 infection. In 2 (3.8\%) CCTs, typical findings of COVID-19 infection were observed. Four (3.7\%) cases were RT-PCR positive. The diagnostic rate of radiological methods (chest X-rays and CCT) for COVID-19 was $1.8 \%$, while that of RT-PCR was $3.7 \%$. CCT had a sensitivity of $50 \%$, a specificity of $98 \%$, and accuracy of $96 \%$ when compared to RT-PCR for the diagnosis of COVID-19 infection during the preoperative screening of asymptomatic patients.

Conclusion: Radiological diagnostic methods such as chest X-ray and CCT should not be mandatorily/routinely suggested because of their

\section{Öz}

Amaç: Preoperatif değerlendirmede Koronavirüs hastalığı-2019 (COVID-19) enfeksiyonu tespiti için akciğer grafisi ve toraks bilgisayarlı tomografisi (TBT) gibi radyolojik tanısal yöntemlerin, burun ve boğazdan alınan sürüntüde çalışlan ters transkriptaz-polimeraz zincir reaksiyonu (RT-PZR) testinin tanı oranlarının karşılaştıııması amaçlandı.

Yöntem: Preoperatif değerlendirilen ve COVID-19 açısından asemptomatik olan 107 olgu; demografik verileri, sürüntü RT-PZR testi sonuçları, akciğer grafileri ve Kuzey Amerika Radyoloji Derneği uzman konsensus COVID-19'a göre tanımlanan TBT'leri ile retrospektif olarak değerlendirildi.

Bulgular: Elli beş $(\% 51,4)$ olgunun akciğer grafisi, $52(\% 48,6)$ olgunun TBT'si vardı. Akciğer grafisi çekilen tüm olguların COVID-19 enfeksiyonu açısından radyolojisi normaldi. TBT çekilen olguların 2'sinde $(\% 3,8)$ COVID-19 enfeksiyonu açısından tipik görüntü izlendi. RT-PZR testi sonuçlarına bakıldığında $4(\% 3,7)$ olgunun sonucunun pozitif olduğu görüldü. Akciğer grafisi ve TBT ile yani radyolojik olarak COVID-19 tanı oranımız \%1,8, RT-PZR ile \%3,7 olarak saptandı. TBT çekilen grupta RTPZR testi referans olarak alındığında preoperatif asemptomatik olgularda COVID-19'u saptamada toraks BT'nin sensitivitesi \%50, spesifitesi \%98 ve doğruluk oranı \%96 olarak saptandı.

Sonuç: COVID-19 açısından asemptomatik olan preoperatif olgularda COVID-19 enfeksiyonunu saptamada RT-PZR'ye ek olarak akciğer grafisi

Address for Correspondence: Güler Özgül, University of Health Sciences Turkey, İstanbul Bağcllar Training and Research Hospital, Clinic of Chest Diseases and Tuberculosis, İstanbul, Turkey

E-mail: gulerozgul@hotmail.com ORCID: orcid.org/0000-0002-1048-1683 Received: 01.08.2021 Accepted: 19.12.2021

Cite this article as: Özgül G, Uğur Chousein EG. Comparison of Radiological Imaging and Reverse Transcriptase Polymerase Chain Reaction Test in Preoperative Screening for Detection of COVID-19. . Bagcilar Med Bull

${ }^{(C)}$ Copyright 2021 by the Health Sciences University Turkey, Bagcilar Training and Research Hospital Bagcilar Medical Bulletin published by Galenos Publishing House. 
low sensitivity in the diagnosis of COVID-19 infection in preoperative screening for asymptomatic cases. More studies with larger patient populations will be more illuminating on this issue.

Keywords: Chest computerized tomography, COVID-19, preoperative screening, RT-PCR test ve TCT gibi radyolojik tanısal yöntemlerin uygulanması düşük sensitivitesi nedeniyle rutin olarak önerilmemelidir, ancak daha fazla sayıda hasta ile daha çok çalışma yapılması bu konuda daha fazla aydınlatıcı olacaktır.

Anahtar kelimeler: COVID-19, preoperatif değerlendirme, RT-PZR testi, toraks bilgisayarlı tomografi

\section{Introduction}

The ongoing epidemic due to severe acute respiratory syndrome-coronavirus-2, which emerged due to a highly contagious RNA virus, was declared a global epidemic (pandemic) by the World Health Organization on March 11, 2020, and Turkey announced its first official case on the same day. Although the virus predominantly affects the upper and lower respiratory tract, it can also cause gastrointestinal, hepatic, renal, cardiac and neurological symptoms, and the disease it causes was named Coronavirus disease-2019 (COVID-19) $(1,2)$.

The most common and specific/typical symptoms of COVID-19 include fever, dry cough, shortness of breath, myalgia, fatigue, headache, sore throat, and diarrhea. While $15.6 \%$ (95\% confidence interval, 10.1-23.0) of confirmed COVID-19 patients may be asymptomatic, the severity of illness can range from simple upper respiratory tract infection to severe pneumonia and acute respiratory distress syndrome (ARDS), arrhythmia, arrhythmia, shock, acute cardiac injury, secondary infection, acute kidney injury, and death $(3,4)$.

Preoperative screening for COVID-19 infection during the pandemic aims to protect both patients undergoing surgery and other patients treated in the same ward, as well as the surgical team. The presence ofCOVID-19 in the preoperative and perioperative period was found to be significantly related to postoperative morbidity and mortality (5). The pulmonary complication rate in COVID-19 patients who underwent surgery was $51.2 \%$, and the mortality rate in these patients was $38 \%$ (6). Based on expert opinion in the early stages of the pandemic and publications in the later periods, reverse transcriptase-polymerase chain reaction (RT-PCR), chest X-ray and chest computed tomography (CCT) were used to detect COVID-19 in preoperative screening. It has been reported that chest X-rays are mostly diagnostic in advanced stages of the disease and have a sensitivity between $37 \%$ and $57 \%$, even in confirmed COVID-19 patients who are symptomatic (7). Therefore, in most centers, the CCT has been a more common imaging modality for radiological diagnosis.
The aim of the study is to compare the diagnostic rates of these three diagnostic methods in the detection of COVID-19 in pre-operative screening and to determine the most convenient method that can be used in daily practice.

\section{Materials and Methods}

The study was approved by the Scientific Board of Yedikule (22.04.2020/114) and the Ministry of Health of the Republic of Turkey (2021-02-05T22_34_57), and it was also carried out in accordance with the Declaration of Helsinki. We retrospectively evaluated 113 patients who presented for preoperative evaluation between August 2020 and December 2020 to the Chest Diseases and Tuberculosis Clinics of University of Health Sciences Turkey, İstanbul Bağcllar Training and Research Hospital. Six patients with a history of prior COVID-19 infection were excluded; the remaining 107 patients were included in the study. Patients were destined for either elective or emergency surgery. Patient data including age, gender, smoking history, concurrent diseases, respiratory examination findings, oxygen saturation, chest X-ray, CCT, swab RTPCR for COVID-19 and the referring clinic were recorded. CCT findings were determined according to the expert consensus on COVID-19 of the Radiological Society of North America (RSNA) (8). According to this,

\section{1- Typical appearance;}

a. Peripheral, bilateral, ground glass opacity (GGO) with or without consolidation or visible intralobular lines ("crazypaving") .

b. Multifocal GGO of rounded morphology with or without consolidation or visible

intralobular lines ("crazy-paving”).

c. Reverse halo sign or other findings of organizing pneumonia (seen later in the disease).

\section{2- Indeterminate appearance;}

Absence of typical features and presence of:

a. Multifocal, diffuse, perihilar, or unilateral GGO with or without consolidation lacking a specific distribution and are non-rounded or non-peripheral. 
b. Few very small GGO with a non-rounded and nonperipheral distribution.

\section{3- Atypical appearance;}

Absence of typical or indeterminate features and presence of:

a. Isolated lobar or segmental consolidation without GGO.

b. Discrete small nodules (centrilobular, "tree-in-bud").

c. Lung cavitation.

d. Smooth interlobular septal thickening with pleural effusion.

\section{4-Negative for pneumonia;}

No CT features to suggest pneumonia.

Swab RT-PCR test, chest X-ray, and CCT were compared for their contribution to COVID-19 diagnosis in the preoperative screening.

\section{Results}

A total of 107 patients were included in the study, 61 (57\%) were male and their mean age was $56.8 \pm 14.5$ years. 60 (56.1\%) cases had a smoking history (active of ex-smoker) with a mean $38.9 \pm 25.7$ pack years. Sixty-six (61.7\%) patients had comorbid diseases such as hypertension in 35 (32.7\%), diabetes mellitus in 27 (25.2\%), coronary artery disease in $16(15 \%)$, malignancy in $10(9.3 \%)$, chronic obstructive lung disease in 7 (6.5\%), neurologic diseases (Alzheimer's disease, epilepsy, multiple sclerosis, migraine) in 9 (8.4\%), hypothyroidism in 4 (3.7\%), asthma in 3 (2.8\%), and chronic renal failure in $1(0.9 \%)$. All patients were asymptomatic for COVID-19. Abnormal respiratory physical examination findings were detected in 6 patients while oxygen saturation was $<90 \%$ in 2 (Table 1 ).

Considering their distribution according to the referring clinics for preoperative evaluation, it was seen that 31 (29\%) of them were referred from general surgery, 18 (16.8\%) from cardiovascular surgery, 15 (14\%) from urology, 11 (10.3\%) from neurosurgery, 9 (8.4\%) from otorhinolaryngology, 7 (6.5\%) from gynecology, 6 (5.6\%) from orthopedics, 5 (4.7\%) from cardiology, 4 (3.7\%) from plastic and reconstructive surgery, and 1 (0.9\%) from ophthalmology (Table 1$)$.

Fifty-five $(51.4 \%)$ patients were preoperatively screened with chest X-rays, and 52 (48.6\%) with CCT. None of the chest X-rays revealed the findings of COVID-19 infection. According to the RSNA, CCT findings were negative for pneumonia in 35 (67.3\%), typical appearances for COVID-19 infection were detected in 2 (3.8\%), undetermined appearances in $5(9.6 \%)$, and atypical appearances in 10 (19.2\%). All cases were evaluated with nasal-throat swab RTPCR test, which was positive in 4 (3.7\%) cases and negative in $103(96.3 \%)$ cases (Figure 1). Two of the RT-PCR positive cases had normal chest X-rays and were subsequently evaluated with CCTs. One had typical appearance for COVID-19 and 1 had undetermined appearance. For the diagnosis of COVID-19 in asymptomatic preoperative patients, the diagnostic rate of radiological evaluation including chest X-ray and tomography was $1.8 \%$, while the diagnostic rate of RT-PCR was $3.7 \%$.

In the preoperative screening of cases for COVID-19 infection, the diagnostic contribution of the swab RT-PCR test was higher than radiological evaluation. This result was attributed to the fact that all cases were asymptomatic, CCT was not obtained from all patients. Because, in our study,

Table 1. General characteristics of study population

\begin{tabular}{|c|c|c|c|}
\hline & & $\mathbf{n}$ & $\%$ \\
\hline Age (mean $\pm \mathrm{SD})$ & & $56.8 \pm 14.5$ & \\
\hline \multirow[t]{2}{*}{ Gender } & Female & 46 & 43.0 \\
\hline & Male & 61 & 57.0 \\
\hline \multirow[t]{2}{*}{ Smoking history } & No & 47 & 43.9 \\
\hline & Yes & 60 & 56.1 \\
\hline Pack/years (mean $\pm \mathrm{SD})$ & & $38.9 \pm 25.7$ & \\
\hline \multirow[t]{2}{*}{ Comorbid diseases } & Yes & 41 & 38.3 \\
\hline & No & 66 & 61.7 \\
\hline Hypertension & & 35 & 32.7 \\
\hline Diabetes mellitus & & 27 & 25.2 \\
\hline Coronary artery disease & & 16 & 15.0 \\
\hline Malignancy & & 10 & 9.3 \\
\hline Neurological disease & & 9 & 8.4 \\
\hline COPD & & 7 & 6.5 \\
\hline Hypothyroidism & & 4 & 3.7 \\
\hline \multicolumn{4}{|l|}{$\begin{array}{l}\text { Distribution of cases according } \\
\text { to departments }\end{array}$} \\
\hline General surgery & & 31 & 29 \\
\hline Cardiovascular surgery & & 18 & 16.8 \\
\hline Urology & & 15 & 14 \\
\hline Brain and neurosurgery & & 11 & 10.3 \\
\hline Ear nose throat & & 9 & 8.4 \\
\hline Gynecology and obstetrics & & 7 & 6.5 \\
\hline Orthopedics and traumatology & & 6 & 5.6 \\
\hline Cardiology & & 5 & 4.7 \\
\hline Plastic and reconstructive & & 4 & 3.7 \\
\hline surgery & & 1 & 0.9 \\
\hline Ocular surgery & & & \\
\hline
\end{tabular}

SD: Standard deviation, COPD: Chronic obstructive pulmonary disease 


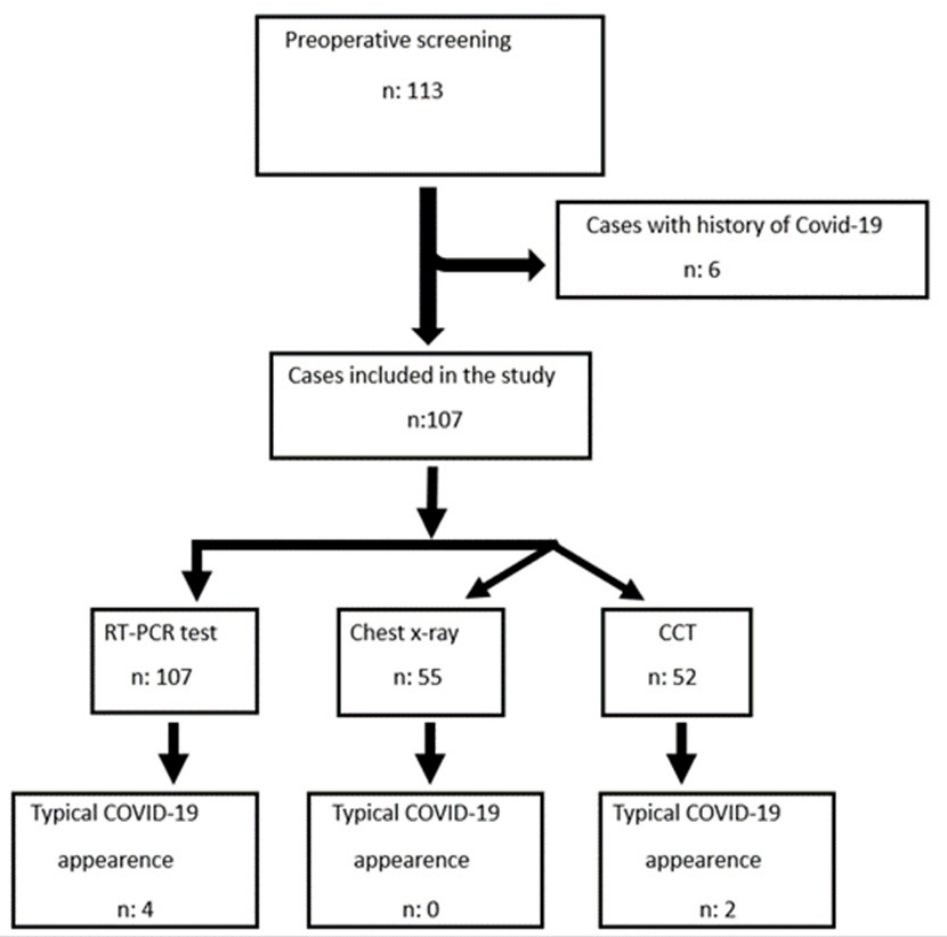

Figure 1. Flow-chart of the study population

COVID-19: Coronavirus disease-2019, CCT: Chest computerized tomography, RT-PCR: Reverse transcriptase-polymerase chain reaction

all chest X-rays were normal for COVID-19, cases with the CCTve RT-PCR test were separately examined. When the RT-PCR test was taken as a reference, the sensitivity of the CCT was $50 \%$, its specificity was $98 \%$, and its accuracy was $96 \%$ in preoperative asymptomatic cases (Table 2).

\section{Statistical Analysis}

Statistical analysis was performed using the SPSS 27.0 program. All categorical variables are presented as percentages. Variables are given as mean with standard deviation, continuous variables are presented as median and range. The Kolmogorov-Smirnov test was used for the distribution of variables.

\section{Discussion}

The use of chest X-ray and/or CCT along with RT-PCR in the diagnostic evaluation of COVID-19 during pandemic has led to many debates. Many studies on this subject reported various conflicting results (9). It is possible that variable factors such as the differences in the possibility of accessing diagnostic tests at different times and incidence periods of COVID-19 and the fact that the studies including the present study were conducted in risky areas such as hospitals and residential areas, where the probability of
Table 2. Comparison of diagnostic methods for asymptomatic preoperative cases for COVID-19

\begin{tabular}{llll} 
& & $\mathbf{n}$ & $\%$ \\
\hline RT-PCR & Yes & 107 & 100 \\
RT-PCR result & Positive & 4 & 3.8 \\
& Negative & 103 & 96.2 \\
Sensitivity/specificity/accuracy & - & - & - \\
Diagnostic rate & & & 3.8
\end{tabular}

Chest X-ray

Typical COVID-19 appearance

$\begin{array}{lll}\text { Yes } & 55 & 51.4 \\ \text { Yes } & 0 & 0 \\ \text { No } & 55 & 100\end{array}$

Sensitivity/specificity/accuracy

Diagnostic rate

Chest CT

Typical COVID-19 appearance

Negative image for COVID-19

Undetermined appearance

Atypical appearance

- $\quad$ - $\quad-$

$0 \quad 0$

Yes $\quad 52 \quad 48.6$

$\begin{array}{lll}\text { Yes } & 2 & 3.8\end{array}$

No $\quad 35 \quad 67.3$

No $\quad 5 \quad 9.6$

No $\quad 10 \quad 19.2$

Sensitivity (RT-PCR taken as a reference) 50

Specificity (RT-PCR taken as a reference) 98

Accuracy (RT-PCR taken as a reference) 96

Diagnostic rate

SD: Standard deviation, RT-PCR: Reverse transcriptase-polymerase chain reaction, CT: Computerized tomography, COVID-19: Coronavirus disease-2019 
encountering COVID-19 is high, might have led to these different results. Also, higher incidence of COVID-19 detection in the study population $(3.8 \%)$ than general population can be explained by the same reasons (2).

Considering that preoperative screening during the COVID-19 pandemic should be different from routine screening programs especially in asymptomatic patients, the study was planned to evaluate the contributions of RTPCR, chest X-ray and CCT to the diagnosis separately and to determine the most convenient one. It was found that the diagnostic rate of the RT-PCR test for detecting COVID-19 was higher than radiological evaluation with a percentage of 3.8 compared to 1.8 .

It is known that chest X-rays can often detect COVID-19 lung involvement in the advanced stages of the disease. However, it can be preferably used as an initial radiologic imaging for case detection in endemic areas or during peak periods of the disease because of its low cost, wide availability and the ease of use of a portable form (10). Sensitivity and specificity of chest X-rays have been found at rates ranging from $25-67 \%$ to $90 \%$, even in symptomatic COVID-19 patients $(7,9)$. Some studies have suggested that chest X-rays should not be used for screening tests or patient follow-up, especially in asymptomatic or oligosymptomatic patients $(1,10)$. In accordance with these suggestions, it was found that none of the chest X-rays of 55 asymptomatic cases showed findings consistent with COVID-19, and 2 (3.6\%) cases had positive RT-PCR.

Different diagnostic sensitivity rates have been reported for CCT, which is used as another radiological diagnostic method in the detection of COVID-19. It was found that CCT's sensitivity is higher but specificity is lower in symptomatic COVID-19 patients. On the other hand, on asymptomatic COVID-19 patients, CCT appears to have lower sensitivity, but higher specificity. In a study by Ai et al. (11), RT-PCR positivity rate among symptomatic patients was found to be $59 \%$ while $88 \%$ of their CCTs had findings compatible with COVID-19. The sensitivity of CCT in detecting COVID-19 was $97 \%$, and its specificity was $25 \%$. The difference between the results of different studies may be attributed to the heterogeneity of the study populations. One study group may consist of contact cases in quarantine, while another group may consist of preoperative cases without any contact. Another reason may be the changing prevalence of the infection with time in that population (12).
Callaway et al. (13) found the sensitivity of CCT as $68.4 \%$ and its specificity as $87.9 \%$ in a study population of mostly negative RT-PCR confirmed 820 cases in whom emergent and elective surgeries were performed in a short time interval with some incomplete data such as whether there was a known delay to surgery and whether the patient subsequently tested positive.

In our study, it was observed that the sensitivity of CCT was $50 \%$, which is low, and its specificity was $98 \%$, which may be explained by the fact that all of our cases were asymptomatic (13).

Gümüs et al. (14), in their study of preoperative 218 asymptomatic cases, had typical CCT findings for COVID-19 pneumonia in $1(0.5 \%)$ patient. They found typical CT findings in only one of the $3(1.4 \%)$ cases who were RT-PCR test positive. Similarly, only 1 of the $4(0.9 \%)$ RT-PCR positive cases in our study showed typical findings in the CCT. When compared to the RT-PCR test, they found that the sensitivity, specificity and accuracy of the CCT in the diagnosis of COVID-19 infection were $33.3 \%$, 90.7\%, and $90.0 \%$ respectively; these results are similar to ours (14). When the results of Chetan et al.'s (15) study were compared to those in the present study, similarity in normal chest X-rays (all normal), typical CCT appearance (3\%), and a slightly higher RT-PCR positivity ratio (1.6\%) was found.

Limited number of study patient population, from a city with a high burden COVID-19 incidence during a short course of pandemic period including a peak time, should all be accepted as the limitations of the study.

\section{Conclusion}

Radiological diagnostic methods such as chest X-ray and CCT should not be mandatorily/routinely suggested because of their low sensitivity in the diagnosis of COVID-19 infection in preoperative asymptomatic cases.

\section{Ethics}

Ethics Committee Approval: Approval was obtained from the Clinical Research Ethics Committee of University of Health Sciences Turkey, Yedikule Chest Diseases and Thoracic Surgery Training and Research Hospital (approval no: 2021/114).

Informed Consent: Patients consent form was waived (not required) because the study was a retrospective observational study.

Peer-review: Externally peer-reviewed. 
Conflict of Interest: No conflict of interest was declared by the authors.

Financial Disclosure: The authors declared that this study received no financial support.

\section{References}

1. Rubin GD, Ryerson CJ, Haramati LB, Sverzellati N, Kanne JP, Raoof $S$, et al. The Role of chest imaging in patient management during the COVID-19 pandemic: a multinational consensus statement from the Fleischner Society. Radiology 2020;296(1):172-180.

2. Recent coronavirus status in Turkey, Ministry of Health Turkey. Erişim adresi: https://covid19.saglik.gov.tr. Published November 01,2021 .

3. He J, Guo Y, Mao R, Zhang J. Proportion of asymptomatic coronavirus disease 2019: A systematic review and meta-analysis. J Med Virol 2021;93(2):820-830.

4. Lei S, Jiang F, Su W, Chen C, Chen J, Mei W, et al. Clinical characteristics and outcomes of patients undergoing surgeries during the incubation period of COVID-19 infection. EClinicalMedicine. 2020;21:100331.

5. Kovoor JG, Tivey DR, Williamson P, Tan L, Kopunic HS, Babidge WJ, et al. Screening and testing for COVID-19 before surgery. ANZ J Surg 2020;90(10):1845-1856.

6. COVID Surg Collaborative. Mortality and pulmonary complications in patients undergoing surgery with perioperative SARS-CoV-2 infection: an international cohort study. Lancet 2020;396(10243):27-38.

7. Ippolito D, Pecorelli A, Maino C, Capodaglio C, Mariani I, Giandola T, et al. Diagnostic impact of bedside chest x-ray features of 2019 novel coronavirus in the routine admission at the emergency department: case series from lombardy region. Eur J Radiol 2020;129:109092.
8. Simpson S, Kay FU, Abbara S, Bhalla S, Chung JH, Chung M, et al. Radiological Society of North America expert consensus statement on reporting chest CT findings related to COVID-19 endorsed by the Society of Thoracic Radiology, the American College of Radiology, and RSNA—secondary publication. J Thorac Imaging 2020;35(4):219-227.

9. Choi H, Qi X, Yoon SH, Park SJ, Lee KH, Kim JY, et al. Extension of coronavirus disease 2019 on chest CT and implications for chest radiographic interpretation. Radiol Cardiothorac Imaging 2020;2(2):e200.

10. Chamorro EM, Tascón AD, Sanz LI, Vélez SO, Nacenta SB. Radiologic diagnosis of patients with COVID-19. Radiologia (Engl Ed) 2021;63(1):56-73.

11. Ai T, Yang Z, Hou H, Zhan C, Chen C, Lv W, et al. Correlation of chest CT and RT-PCR testing for Coronavirus Disease 2019 (COVID-19) in China: a report of 1014 cases. Radiology 2020;296(2):E32-E40.

12. Vafea M, Atalla E, Kalligeros M, Mylona EK, Shehadeh F, Mylonakis E. Chest CT findings in asymptomatic cases with COVID-19: a systematic review and meta-analysis. Clin Radiol 2020;75(11):876.

13. Callaway M, Harden S, Ramsden W, Beavon M, Drinkwater K, Vanburen T, et al. A national UK audit for diagnostic accuracy of preoperative CT chest in emergency and elective surgery during COVID-19 pandemic. Clin Radiol 2020;75(9):705-708.

14. Gümüs T, Kabaoglu ZU, Coskun B, Kartal F, Artukoglu F, Atasoy KC. Preoperative computerized tomography screening for COVID-19 pneumonia in asymptomatic patients: experiences from two centers. Jpn J Radiol 2021;39(3):240-245.

15. Chetan MR, Tsakok MT, Shaw R, Xie C, Watson RA, Wing L, et al. Chest CT screening for COVID-19 in elective and emergency surgical patients: experience from a UK tertiary centre. Clin Radiol 2020;75(8):599-605. 